\title{
Diachronic transformations of urban routes for the theory of attractors
}

\author{
Alessandro Camiz ${ }^{2}$ \\ ${ }^{1}$ Department of Architecture, Girne American University, Cyprus \\ ${ }^{2}$ AHDR, Home for Cooperation (H4C), Nicosia, Cyprus \\ E-mail: alessandrocamiz@gau.edu.tr
}

\begin{abstract}
Recent urban morphology studies consider urban tissues as living organisms changing in time (Strappa, Carlotti, Camiz, 2016), following this assumption the urban morphology theory should examine more analytically what Muratori called 'medievalisation' (Muratori, 1959), a term describing some of the transformations of urban routes happened in the middle ages. The paper considers the diachronic deformation of routes, and other multiscalar occurrences of the attraction phenomena (Charalambous, Geddes, 2015), introducing the notion of attractors and repellers. Archaeological studies already do consider attractors and repellers as a tool to interpret some territorial transformations, following the assumption that "the trajectory that a system follows through time is the result of a continuous dynamic interaction between that system and the multiple 'attractors' in its environment" (Renfrew, Bahn, 2013, p. 184). There are different elements that can act as attractors in an urban environment, such as bridges, city walls, city gates, water systems, markets, special buildings, and it is possible to consider each of these anthropic attractors as equivalent to a morphological attractor at the geographical scale. We can even interpret the ridge-top theory (Caniggia, 1976) as the result of attraction and repellence of geographic features on anthropic routes. The territorial scale analysis is the methodological base of the theory, but the attractors herein considered operate at the urban scale, deviating locally across time from a rectilinear trajectory and defining a specific urban fabric. The research interprets and reads the effects of attractors on urban routes and fabrics as a method for the reconstruction of Nicosia's medieval city walls, in continuity between the Conzenian approach (Whitehand, 2012) and the Italian School of Urban Morphology (Marzot, 2002).
\end{abstract}

Keywords: Attractors, repellers, urban routes, urban morphology, theory, history.

"He maketh me to lie down in green pastures: he leadeth me beside the still waters" Psalm 23, 2, KJV.

\section{Introduction}

The attractor theory is a new experimental tool of analysis in the urban morphology field, introducing a diachronic analysis of the configuration of routes. Routes change in time and we can interpret some of the deformations they follow as the result of the attraction or repellence of certain artefacts, defined here as attractors or repellers. Once an attractor appears into an urban network of routes, it may happen that some paths change their configuration and deviate from their former position. Archaeological studies have introduced the same notion of attractor and repeller as a tool to interpret some territorial transformations, following the assumption that "the trajectory that a system follows through time is the result of a continuous dynamic interaction between that system and 
the multiple 'attractors' in its environment" (Renfrew, Bahn, 2013). Mathematicians also use the notion of attractor with a quite different meaning, as a set of numerical values toward which a system evolves in the long term. There is a number of studies on urban planning deriving the notion of attractor from the mathematical concept and applying it to the statistical study of settlement patterns. (Boeing, 2016). Some archaeologists have borrowed the theory of attractors from mathematics to explain cyclical or "strange" transformations using the point, limit cycle, toroidal, strange attractor division (McGlade, 1995), (McGlade, Van Der Leeuw, 1997). Space Syntax studies have introduced the term attractor to name an element attracting pedestrian movement; and other connected concepts such as the spatial layout attraction, the land use attraction and the transport attractions. In this discipline, an attractor is a building or any other feature with the potential of generating trips to and from a place. A negative attractor is instead an element decreasing the natural movement rates. (Hillier, Penn, Hanson, Grajewski, Xu, 1993). The attractor as defined in Space Syntax differs from the one we are introducing here but is useful for the explanation of the theory, as it refers to pedestrian movement, which happens usually before the street itself is built. The traffic may therefore influence the planimetric shape of a route as attracted in time. The route, street or lane is a human artefact and we can study it just like buildings and urban tissues. Moreover the level of permanence of routes is in general higher than that of buildings, while the most buildings are private (base buildings) and only few are collective (special buildings), routes instead are in general public and should be considered as collective artefacts. In the long term, streets can tell much more history than buildings.

\section{Methodology}

The object of this research is the analysis of the planimetric configurations of streets in urban environment, recognising typical configurations, and their diachronic transformations due to the effect of the attractors. This analysis can be useful for different disciplines, such as archaeology, urban history, and urban planning. We can define an attractor as an element that deviates a route from its previous configuration by attracting its traffic. A repeller is the inverse of an attractor, an element deforming the configuration of a path by repelling its traffic. An attractor now not existing anymore may be inferred with the formal analysis of the configuration of routes that have been attracted by it, determining a sort of diachronic urban stratigraphy. It is therefore possible to infer the presence, type and position of a former attractor by recognising the deformations of the routes that were attracted by it. In case of disappearance of an attractor or repeller, the configuration of the routes modified can return to its former position or not, depending on the presence of other urban elements preventing its elasticity, as built urban tissues, or even property divisions. I absence of any retaining other structure, once the attraction ceases the route goes back to its undeformed shape. Considering that every route pre-exists its settlement (Caniggia, 1963), the planimetric form of the route depends on a number of elements attracting and repelling its course from the shortest path. These elements, defined here as attractors and repellers, can appear, disappear, or even change position in time, determining through history the complex configuration of the route itself. The changing positions of the attractors and the changing strength of attraction can be recognised and used to interpret the phases of an urban settlement. Once an attractor ceases to exist or ceases to attract, it may happen that the route returns to its unattracted configuration, but in urban areas, urban tissues reduce this elasticity limiting the possibility of reversing the attraction phenomena, freezing therefore the attracted configuration. As a first classification based on the observation of different case studies we considered point attractors, continuous attractors, and shaped or areal attractors. Examples of point attractors may be wells, city gates, bridges, fords, springs, and mountain passes. Examples of continuous attractors are instead city walls, rivers, seashores, lakeshores, canals, while shaped or areal attractors are buildings, infrastructures, 
rock formation, lakes. Attractors can be territorial or urban: some special buildings or urban functions may act as attractors, typically, markets, power seats (government buildings, local administration buildings), churches, monasteries, other religious buildings. The only difference between a territorial and an urban attractor is the urban environment, as a city may significantly change in time. A territorial attractor in a subsequent phase may find itself inside a city, and on the other hand, what was once an urban attractor could today be in an abandoned territory becoming thus territorial. Distinguishing between nodal and polar attraction, includes the notion of pole/antipole and node as defined in the Muratorian theory
(Caniggia, Maffei, 1979). The attractor itself is not nodal or polar, but the attraction point can be nodal or polar in relation to how the different routes are converging there, a nodal attractor is determining a branching between two or more routes, while a polar or antipolar attractor determines the origin or destination of a route. Attraction can be deformed or undeformed, where a deformed attraction is visible in the local modified configuration, while routes that don't have a local curvature converge in an undeformed attractor. Attractors and repellers can be simple or complex depending on how the effects of their action re classified, either in a simple form or as the result of different forms merged together. Finally attractors and
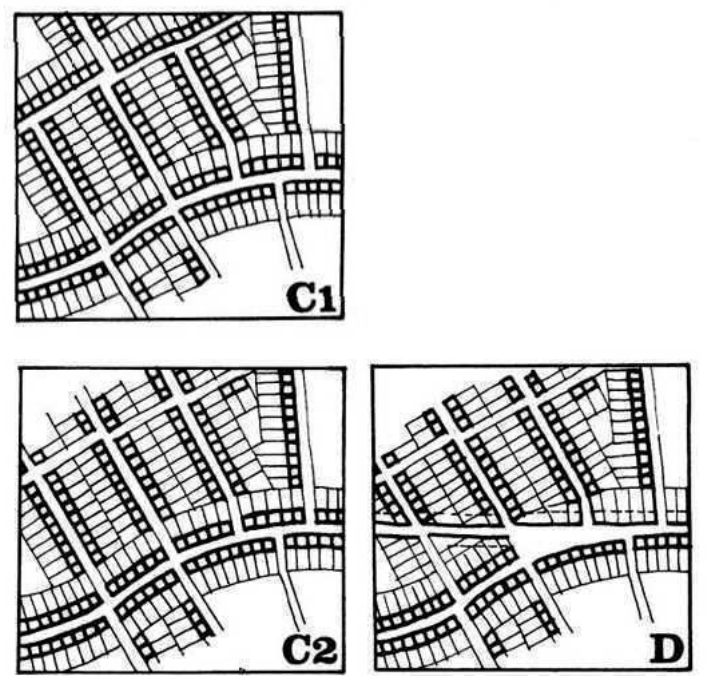

A
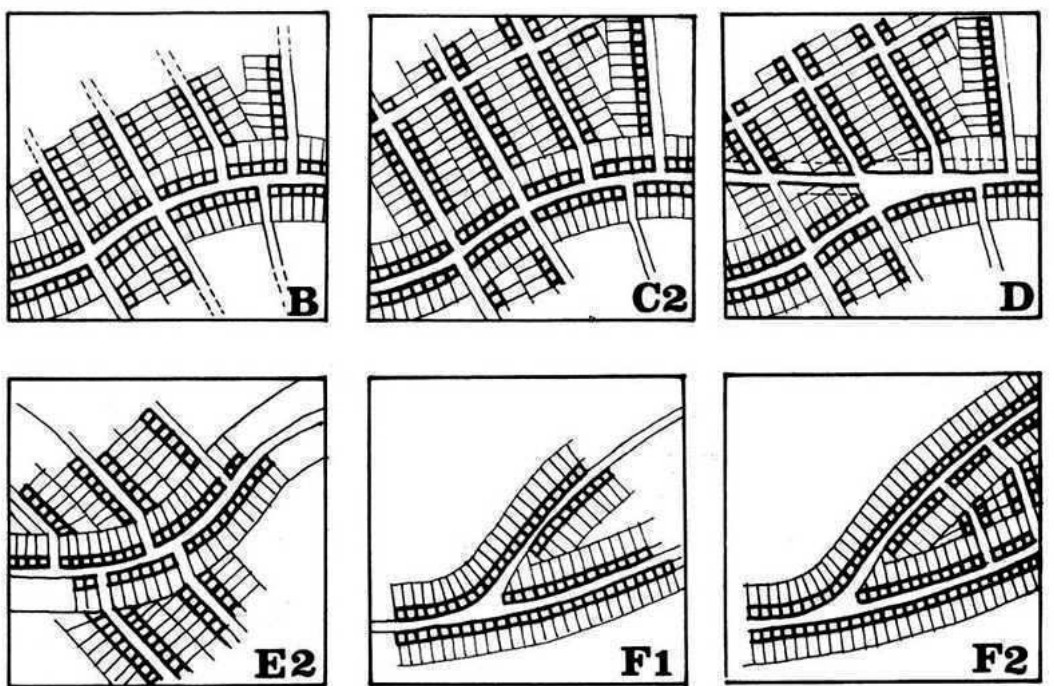

$\mathbf{E 2}$
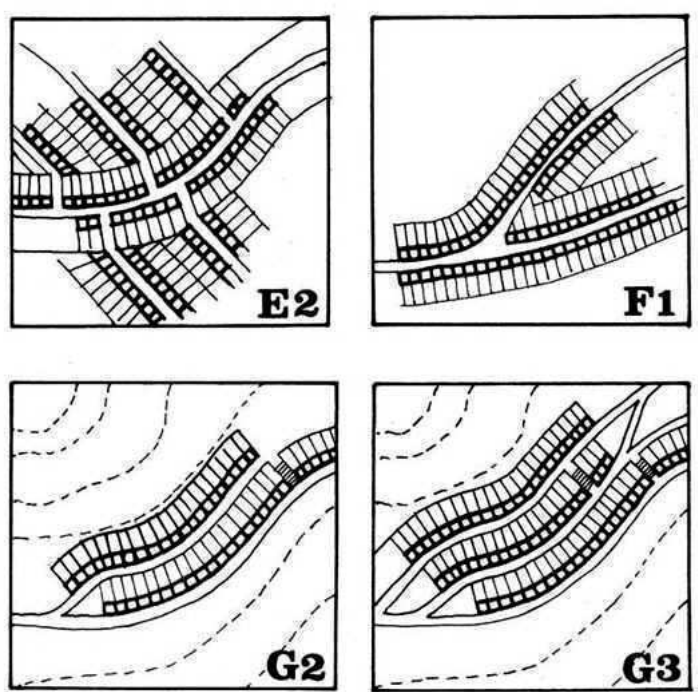

Figure 1.

Variations of urban tissues for different site morphologies (Caniggia and Maffei, 1979). 

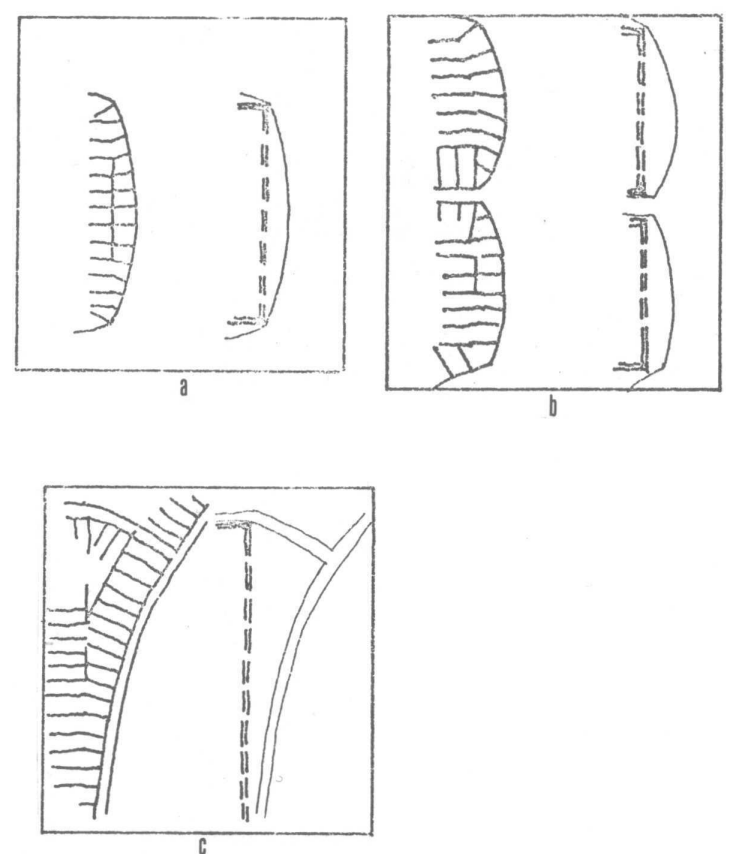

Figure 2.

The medievalisation and the diagonalisation process (Caniggia, 1976).

repellers can be anthropic or natural, depending if they are determined or not by human action. This classification is tentative, and is based on the observation of the attraction phenomena in the urban and territorial environments. The classification is useful to build a taxonomy of attraction cases, based on a binary set or parameters, and to recognise the attractor type. So following the classification there could be an anthropic point nodal undeformed simple attractor, as well as a natural continuous deformed complex attractor. The main characters that need to be recognised in the road network, besides the road curvature and inflection, are the discontinuities in the track, the bifurcations, the intersections and the convergences.

\section{Measurement and analysis}

Looking at the variations of urban tissues for different site morphologies (figure 1) (Caniggia and Maffei, 1979). we understand that the urban routes and therefore the urban tissues are strongly affected by the morphology of the site, as if the site was acting like an attractor. Nevertheless, it is not possible, if not in a geological time scale, that the changing morphology of a site affects and deforms the configurations of the routes. Therefore, the attraction of a natural attractor is permanent and not very useful to reconstruct diachronically the changes of the routes. Anyhow the shortest path from one point to another on a flat surface is a straight line, if the surface has a complex form instead the patch tends to follow the minimum energy path. In this case, the morphology of the site acts as an attractor to the route, deforming its theoretical straight shape. The first step in the construction of the theory consists in the classification of the natural attractors. The theory is based on the assumption that every anthropic attractor has an equivalent natural attractor. There are different elements that can act as attractors in an urban environment, such as bridges, city walls, city gates, water systems, markets, special buildings, and it is possible to consider each of these anthropic attractors as equivalent to a morphological attractor at the geographical scale. We can even interpret the ridge-top theory (Muratori, 1959) as the result of attraction and repellence of geographic features on anthropic routes. Even the fringe belt phenomenon can be described as the attraction of the city on the urban services together with the repellence of the built urban issue on their localisation (Whitehand and Morton 2006), (Maretto, 2009). The territorial scale analysis is the methodological base of the theory, but the attractors herein considered operate at the urban scale, deviating locally across time from a rectilinear trajectory and defining therefore a specific urban fabric. A natural point attractor is as an example a ford: the position of the ford, which is in general independent form the morphological configuration of the territory, will deviate the routes following the ridge top theory so to cross the river in that specific point. The equivalent anthropic attractor is a bridge. While the ford in the human time scale probably does not change, and the deformation of the route from its theoretical shape is stable, in the case of the bridge, its existence and position can vary in time, so the deformation of the routes can be dynamic. Following the analogy between the mountain pass and the city gate, it is possible to recognize the typical feature of the bifurcation 
of routes converging from the territory to the city gate. This $\mathrm{Y}$ shaped bifurcation (Figures 5 and 6) happens when the construction of new city walls and gates, forces a pre-existing street leading to the city centre to abandon its configuration and merge outside of the city entrance with the other route that attracted the construction of the gate in that position. In this case, one of the routes is acting as an attractor for the position of the gate, and subsequently it is the gate acting as point attractor to the other routes. Therefore, it is possible to distinguish an undeformed route merging into the bifurcation, and a deformed one. We can recognise this configuration in the bifurcations outside of Porta Ravegnana in the medieval Bologna, in this case the Kardo of the roman Bononia, via Aemilia, continues undeformed outside of the roman city walls, while the other routes were attracted converging in the gate. The same phenomenon can happen inside the city, either because the urban tissue is not consolidated yet or with the restructuring of the former urban tissue. A good example of an inner bifurcation of routes for the city gate acting as attractor may be found in Porta del Popolo and the three streets via del Babuino, via Lata and via Ripetta. In this case the via Lata is the unattracted route, the other two, as determined in the XVI century with the Piano Sistino, were designed to converge in the square facing the city gate inside the city. By finding typical configurations of road bifurcations, branching, intersections, and deformations from the straight form, interpreted diachronically, it is possible to construct an abacus of the attractors and repellers, and the deformations caused on the urban routes. With the analytical understanding of a very large number of cases and their explanation in theoretical terms, it will be possible to provide a substantial aid to the study of the history of cities in the middle ages: a historical phase of history that usually lacks documentation for the reconstruction of the urban environment. Recognising these deformations can help us to reconstruct as an example a bridge now not existing anymore. Another natural point attractor is the mountain pass, and its anthropic equivalent the city gate. The linear attractor is instead a continuous structure deforming a route to follow it. Natural continuous attractors are mountain ridges, riversides, lake and seashores. By generalising the ridge top theory, we can say that routes within certain conditions take the shape of the continuous attractors. In some cases, the same element attracting can act as a repeller for other routes. As an example we can consider the ridge top that attracts the route, but if too sharp and steep, deviates the route from its edge (repeller) keeping it though close to it (attraction). City walls are an example of a complex attractor,

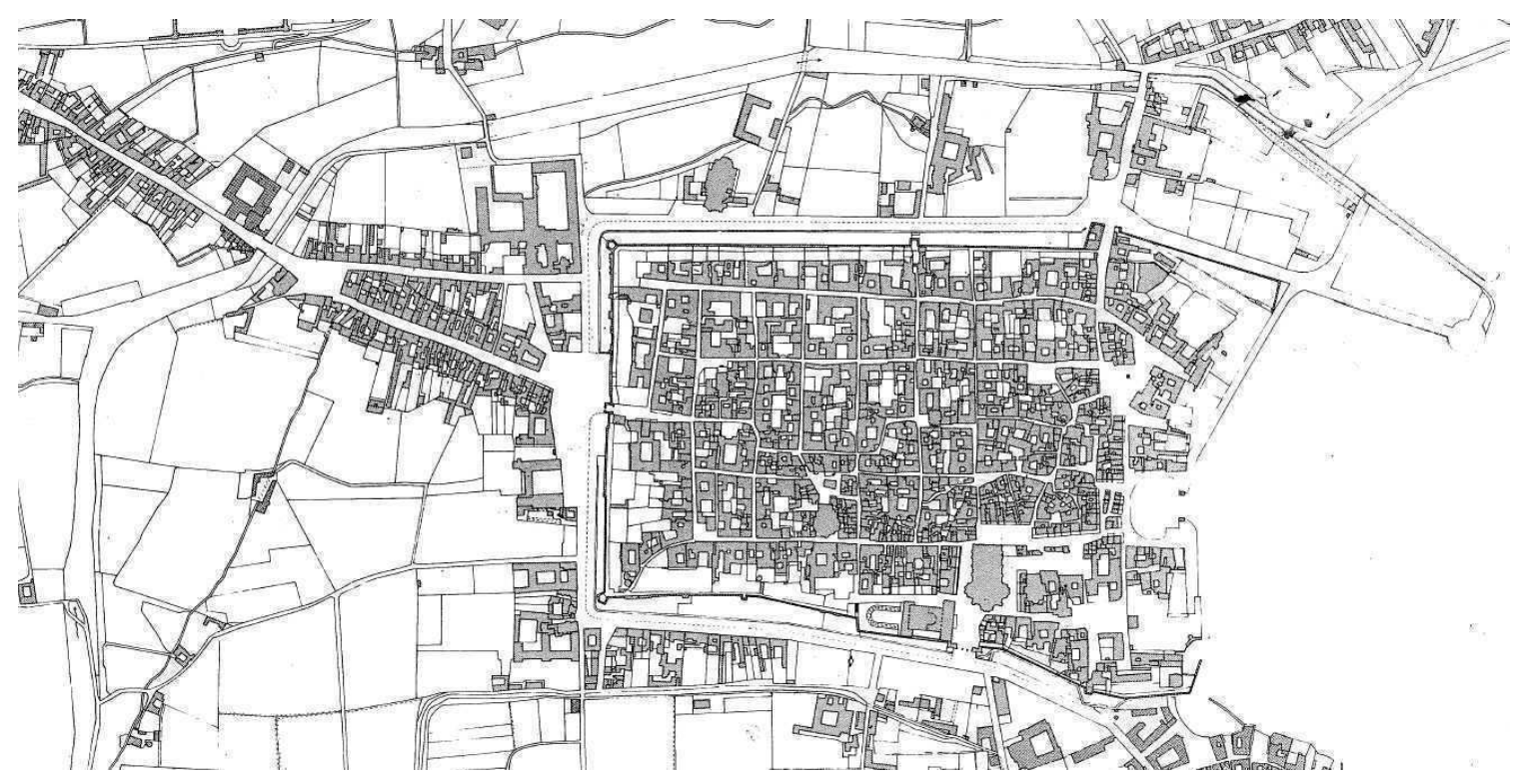

Figure 3.

Como: plan reconstructed from the 1858 cadastre (Caniggia, 1963). 


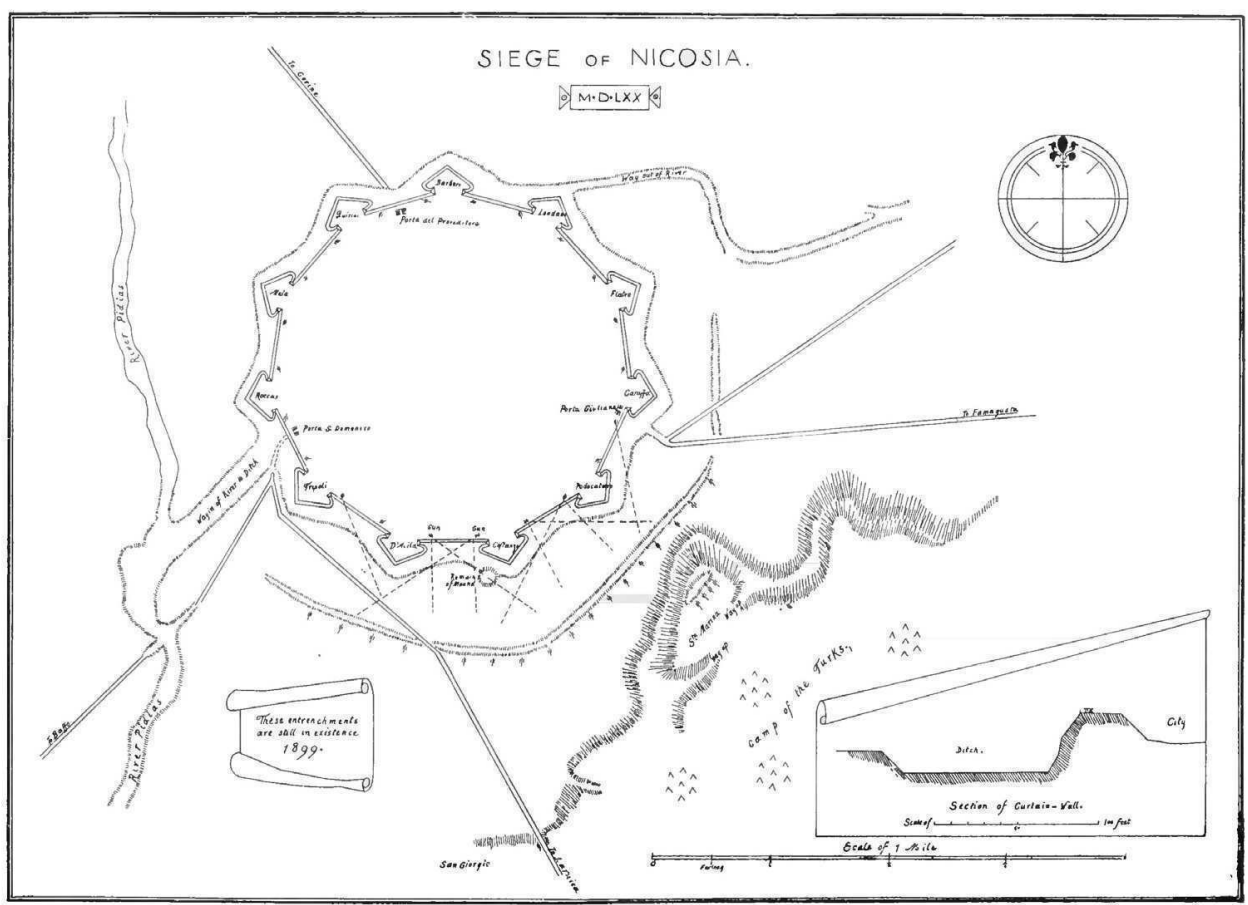

Figure 4.

The attraction of the three Venetian city gates of Nicosia (1567) on the external routes. (Cobham, 1908, p.87).

as generally they attract the paths inside the precinct to follow their perimeter, and instead repel the former path to follow their perimeter on the outside. The city gate instead acts as a point attractor for the inside and outside routes. Very often the position of the gate is attracted by one of the existing routes on the moment of its foundation, while in a second phase the routes tend to converge in the gate ending with the bident or trident configuration. The very same configuration happens usually with a bridge over a river, where the two valley bottom routes on either side of the river are attracted and deformed by the river's shape that can indeed change in time, and the routes converge in the position of the bridge. Figure 5 and 6 are an attempt of categorising the attraction phenomena, and describe in time some cases. The diachronic evolution of a path for the appearance of a point attractor A close to the path is described in the first case. The trajectory of a route from pole 1 to antipole 2 is the shortest path in the time T0; in $\mathrm{T} 1$, the point attractor A appears and in T2 it inflects the linear trajectory of the shortest path determining inflection points $\mathrm{f} 1$ and $\mathrm{f} 2$. It is possible that the bifurcations b1 and b2 appear in $\mathrm{T} 3$ as the inflected path takes the role of an alternative course (Figure 5, SA1). The behaviour of the path in case of a repeller $\mathrm{R}$, is not symmetrical as the point repeller $\mathrm{R}$ along the path deflects the linear trajectory of the shortest path determining the inflection points f1 and $\mathrm{f} 2$ but there are 2 distinct alternatives in the trajectory to avoid the repeller, determining a bifurcation (Figure 6, SP1). The medievalisation as explained by Caniggia (1976), can be interpreted as the persistence of attraction of the street corners, while the street is repelled by the growing urban tissue (Figure 6, CP1). While the diagonalisation (Caniggia, 1976) can be described as the existing precinct of the forum acting as a repeller, and after disappearing the streets take the shortest path as attracted by the block corners acting as attractors. (Figure 6, CP1).

\section{Conclusion}

The research interprets and reads the effects of attractors on urban routes and fabrics as a method for the reconstruction of Nicosia's medieval city walls. An ongoing research is 


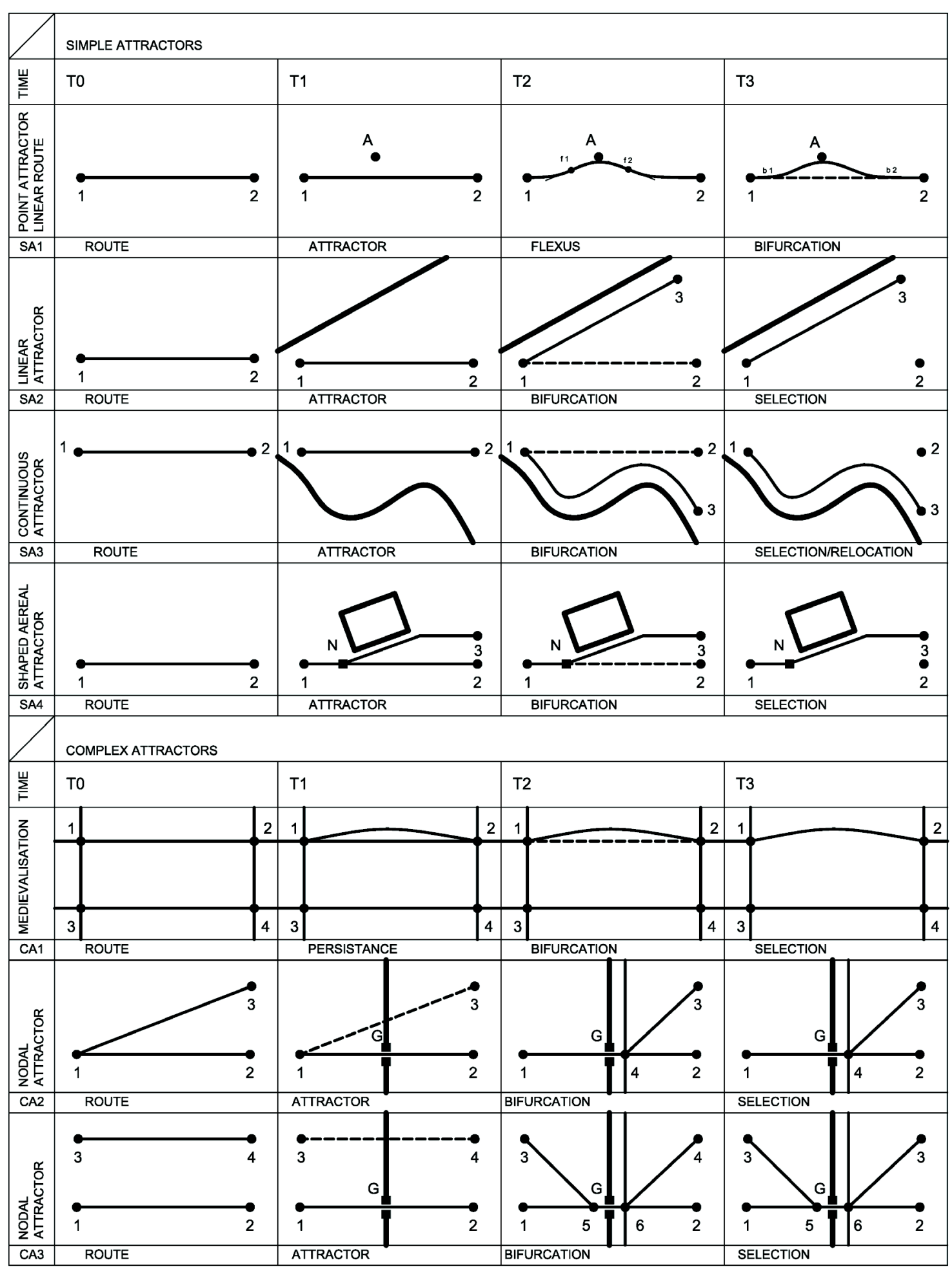

Figure 5.

Simple and complex attractors, diachronic transformation of urban routes (drawing A. Camiz).

aimed at the reconstruction of the different phases of Nicosia City walls, from the byzantine "circla", to the later teichokastron, and the walls built by the Lusignans in the XIV century, comparing them with coeval cases for each phase, such as Bononia (Guidoni, Zolla, 2000), the territorial routes around Cagliari (Cadinu, 1998) and the city of Como (Caniggia, 


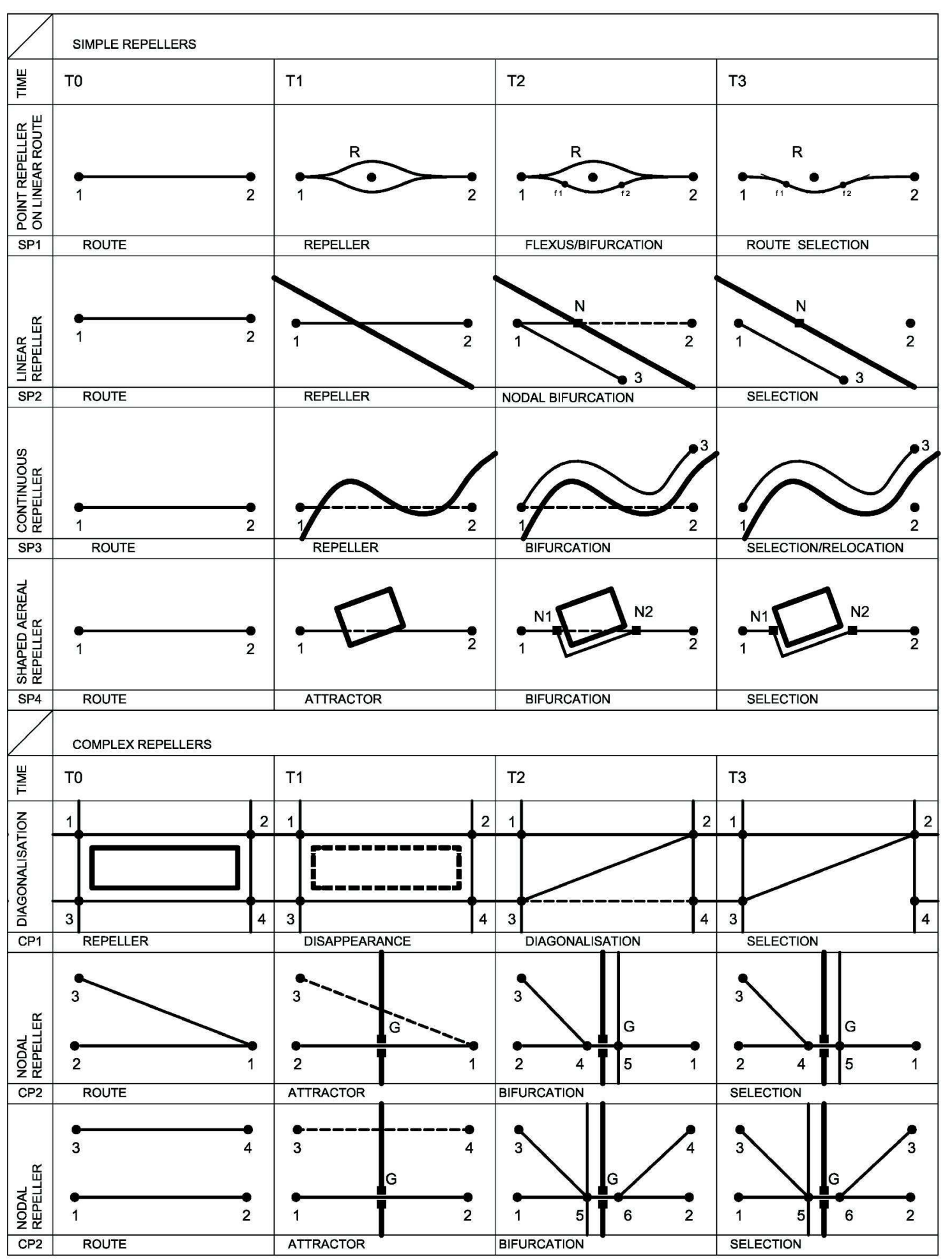

Figure 5.

Simple and complex repellers, diachronic transformation of urban routes (drawing A. Camiz).

1963). The reconstruction is based on the cross matching of historical sources, archaeological evidence and the Muratorian (Strappa, Ieva, Dimatteo, 2003), (Cataldi, Maffei, Vaccaro,
2002), (Ieva, 2015) urban morphology analysis methods: this case study was experimentally proposed for the development of the theory of attractors. The research on the medieval 
walls is not finished yet, so cannot be entirely presented here. Some preliminary considerations on the topography of Nicosia can be discussed as a first application of the theory. The urban settlement of Nicosia started as Ledra in Bronze Age on the top of Agios Georgios hill, next to the river Pedeios (Kanl1 Dere), along the intersection of the valley route following that river, and the cross-valley route connecting the Pentadaktylos ridge and the Troodos ridge, and developed as an exchange point between the two sides of the river. Only in Byzantine times, in the $\mathrm{X}$ century, the city became the capital of the island, and a surrounding wall was added. After becoming archbishopal seat in 1212, the city grew larger. Nicosia was protected since Byzantine times by a walled enclosure of which very little is known. Later the city was defended by a castle built by Henry I in 1211. A complete city wall surrounding the city was started in 1368 by Peter I and completed by Peter II in 1380. Further works were accomplished by Janus I in 1426, and planned in 1450 following Nicholas $\mathrm{V}$ decision. The urban area reached a circumference of four miles, before the Venetian transformation of the city, reduced it to three miles (Mariti, 1792). In 1567 new walls, designed by the Venetian engineers Giulio Savorgnano and Francesco Barbaro, replaced the medieval ones. The construction of the new walls implied the destruction of the older walls, and the infilling of the river, moving its waters into a new moat surrounding the new city walls. A new urban tissue gradually replaced the riverbed, flanked by the sinuous streets that followed its former course inside the ancient city. In Nicosia the three existing bridges, where crossroads connected the two sides of the city, maintained their polar role after the river infilling. The Venetians might have not completed this urban transformation, hence the Ottoman siege of the city in 1570 , but in continuity with the precedent administration the Ottoman renovation of the city, used some of the areas above the infilled river. Since then, this area become the city centre. The three bridges disappeared from the urban landscape once the river was infilled, but their trace is still readable in the network of urban routes. The bridges acted as attractors for the urban routes.
The crossing point of a river determined by a bridge or a ford, acts definitely as a point attractor for the surrounding existing routes. What is singular is that the Ledra Street check point, the only crossing point of the buffer zone within the walled city of Nicosia, was opened in the same point were in ancient times one of the three bridges was; so the permanence of urban traces acted as a guide for the modern design process. After the opening of the checkpoint in 2008 , in the same position of the ancient bridge, all the commercial activities of the walled city of Nicosia were attracted along that same urban axis of Ledra Street, showing a singular cyclical continuity in the attraction phenomenon. In the plan of Nicosia, it is possible to recognise through the inflection and bifurcation analysis a number of meaningful cases. We will propose just a few here, due to the lack of space. The construction of the Kyrenia gate in the end of the XVI century, seems to have attracted the urban axis stemming from the third Royal Palace built in Lusignan times. Maybe in that time the urban tissue was not completed in that zone, and the palace within a fringe belt, was built at the limit of the built area. What is clearly visible in the plan is the attraction of the gate in relation to the urban route, as if the direction of the route was determined by the gate, so to infer that the route developed after the XVI century. In the same area it is possible to hypothesize the presence of a continuous attractor, surrounding the urban tissue, such as a city wall or a moat. On the western side of the city walls, the now called Paphos gate, inflects and bifurcates the outer routes, where the southern one is also deformed by the bastion, acting in this case a repeller. The opening of the Limassol gate in modern times the southern part of the Venetian city walls, attracted the outside routes, and was attracted by the internal ones (Fig. 4). The analysis of a high number of cases of attraction and repellence in urban routes can lead to the further understanding of the diachronic transformation of streets in an urban environment and constitute an instrument for the reconstruction of the different historical phases of an urban settlement, determining the position of city walls, city gates, bridges and other public building 


\section{References}

Boeing, G., (2016). 'Visual Analysis of Nonlinear Dynamical Systems: Chaos, Fractals, Self-Similarity and the Limits of Prediction'. Systems. 4 (4), 37-54.

Cadinu, M. (1998). Persistenze centuriali nell'agro caralitano, in M. Khanoussi, P. Ruggeri, C. Vismara (eds.). L'Africa Romana XII, Atti del Convegno internazionale di studi, Università degli Studi di Sassari, Dipartimento di Storia, (Olbia, 12-15 dicembre 1996), II, (edizioni Edes, Sassari) 695-707.

Camiz A., Bruccoleri A., Baydur S., Atmaca G. (2016). Venetian defence in the Mediterranean: Nicosia's city walls, Cyprus (1567-1570). in Verdiani G. (ed.), Defensive architecture of the Mediterranean. XV to XVIII Centuries, III, (DIDApress, Firenze). 363-370.

Camiz A., Khalil S.I., Demir S.C., Nafa H. (2016). The Venetian defense of the Mediterranean: the Kyrenia Castle, Cyprus (1540-1544). in Verdiani G. (ed.), Defensive architecture of the Mediterranean. XV to XVIII Centuries, III. (DIDApress, Firenze) 371-378.

Camiz A., Kozan H., Suleiman I. (2016). Giovanni Girolamo Sanmicheli and Luigi Brugnoli's design for Famagusta city walls, Cyprus (1550-1562). in Verdiani G. (ed.), Defensive architecture of the Mediterranean. $\mathrm{XV}$ to XVIII Centuries, III (DIDApress, Firenze) 379-386.

Caniggia G. (1976). Strutture dello spazio antropico. Studi e note. (Uniedit, Firenze).

Caniggia, G. (1963). Lettura di una città: Como. (Centro studi di storia urbanistica, Roma).

Caniggia, G., Maffei, G.L. (1979). Lettura dell'edilizia di base. (Marsilio Venezia).

Cataldi, G., Maffei, G.L., Vaccaro, P. (2002). 'Saverio Muratori and the Italian school of planning typology', Urban Morphology. 6 (1), 3-14.

Charalambous N., Geddes I. (2015). 'Making Spatial Sense of Historical Social Data'. Journal of Space Syntax, 6 (1), 81-101.

Cobham C.D. (1908). Excerpta Cypria: materials for a history of Cyprus. (University
Press, Cambridge).

Guidoni E. (1974). 'L'architettura delle città medievali. Rapporto su una metodologia di ricerca (1964-74)'. Mélanges de l'Ecole française de Rome. Moyen-Age, Temps modernes. 86(2), 481-525.

Guidoni, E., Zolla, A. (2000). Progetti per una città. Bologna nei secoli XIII e XIV (Bonsignori, Roma).

Hillier, B., Penn, A., Hanson, J., Grajewski, T., and Xu, J. (1993). 'Natural Movement: or. Configuration and Attraction in Urban Pedestrian Movement'. Environment Planning B: Planning and Design, 20(1), 29-66.

Ieva, M. (2015). 'Urfa: the planned city and the process of medievalization', Key Engineering Materials, 628, 3-8.

Maretto, M. (2009). 'Fringe belt theory and polarities landmarks theory'. Urban Morphology. 13(1), 76.

Maretto M. (2013). 'Saverio Muratori: towards a morphological school of urban design', Urban Morphology, 17 (2), 93-106.

Mariti, G. (1792). Travels through Cyprus, Syria, and Palestine; with a general history of the Levant, I, (Dublin).

Marzot N. (2002). 'The study of urban form in Italy'. Urban Morphology, 6 (2), 59-73.

McGlade, J. (1995). 'Archaeology and the ecodynamics of human-modified landscapes'. Antiquity, 69(262), 113-132.

McGlade, J., Van Der Leeuw, S. E. (1997). Introduction: Archaeology and non-linear dynamics: new approaches to long-term change. In Van Der Leeuw, S. E., McGlade, J. (eds.). Time, Process, and Structured Transformation in Archaeology. (Routledge, London) 1-3.

Muratori S. (1959). Studi per un'operante storia urbana di Venezia. (Istituto Poligrafico dello Stato, Roma)

Renfrew C., Bahn P. eds. (2013). Archaeology: The Key Concepts. (Routledge, London).

Strappa G., Carlotti P., Camiz A., (2016). Urban Morphology and Historical Fabrics. Contemporary design of small towns in Latium, (Gangemi, Roma).

Strappa, G., Ieva, M., Dimatteo, M.A. (2003). La città come organismo: lettura di Trani alle diverse scale. (M. Adda, Bari). 
Whitehand, J.W.R., Morton, N.J. (2006

). 'The Fringe-belt Phenomenon and Socioeconomic Change'. Urban Studies. 43(11), 2047-2066.

Whitehand, J.W.R. (2012) 'Issues in urban morphology', Urban Morphology 16.1, 5565. 